\title{
On the Use of Milk Composition Measures to Predict the Energy Balance of Dairy Cows
}

\author{
N. C. Friggens, ${ }^{* 1}$ C. Ridder, ${ }^{\dagger} \dagger$ and P. Løvendahl ${ }^{*}$ \\ *University of Aarhus, Faculty of Agricultural Sciences, Research Centre Foulum, 8830 Tjele, Denmark \\ †Lattec I/S, 3400 Hillerød, Denmark
}

\begin{abstract}
Milk composition varies with energy status and was proposed for measuring energy balance on-farm, but the accuracy of prediction using monthly samples is not high. With automated sampling and inline milk analysis, a much higher measurement frequency is possible, and thus improved accuracy of energy balance determination may be expected. Energy balance was evaluated using data in which milk composition was measured at each milking. Three breeds (Danish Holstein, Danish Red, and Jerseys) of cows (623 lactations from 299 cows) in parities 1, 2, and 3+ were used. Data were smoothed using a rolling local regression. Energy balance (EBal) was calculated from changes in body reserves (body weight and body condition score). The relationship between EBal and milk measures was quantified by partial least squares regression (PLS) using group means data. For each day in lactation, the within-breed and parity mean EBal and mean milk measures were used. Further PLS was done using the individual cow data. The initial PLS models included 25 combinations of milk measures allowing a range of nonlinear effects. These combinations were as follows: days in milk (DIM); DIM raised to the powers 2, 3, and 4; milk yield; fat content; protein content; lactose content; fat yield; protein yield; lactose yield; fat:protein ratio; fat:lactose ratio; protein:lactose ratio; and milk yield:lactose ratio, together with 10 "diff()" variables. These variables are the current minus the previous value of the milk measure in question. Using group means data, a very high proportion (96\%) of the variability in EBal was explained by the PLS model. A reduced model with only 6 variables explained $94 \%$ of the variation in $\mathrm{EBal}$. This model had a prediction error of $3.82 \mathrm{MJ} / \mathrm{d}$; the 25 -variable model had a prediction error of $3.11 \mathrm{MJ} / \mathrm{d}$. When using individual rather than group means data, the PLS prediction error was 17.3
\end{abstract}

Received December 6, 2006.

Accepted July 13, 2007.

${ }^{1}$ Corresponding author: n.friggens@agrsci.dk
$\mathrm{MJ} / \mathrm{d}$. In conclusion, the mean Ebal of different parities of Holstein, Danish Red, and Jersey cows can be predicted throughout lactation using 1 common equation based on DIM, milk yield, milk fat, and milk protein measures.

Key words: milk composition, energy balance, dairy cow, body condition

\section{INTRODUCTION}

The energy balance of dairy cows has traditionally been measured in 2 ways: input-output measures and body reserve change. The first method requires the measurement of all energetic inputs (feed intake) and outputs (milk, fetus, growth) and is not feasible under current commercial conditions. Body reserve change is measured from changes in BW and BCS. Measuring $\mathrm{BW}$ and BCS is feasible in practice but is not well suited to assessing short-term changes in energy status due to the relative insensitivity of condition score scales. Further, both methods can be associated with a significant measurement uncertainty (Coffey et al., 2001). A third option that was put forward for measuring energy balance is from changes in milk composition, most likely changes in milk fat and protein contents. This option, if it has an adequate level of accuracy, is an attractive one, because it could provide a cheap and reliable estimator of energy balance.

The use of milk composition, in particular, fat:protein ratio, to indicate energy status has been around for some time (Grieve et al., 1986). The biological basis for this relationship lies in 2 tendencies: a mechanism that maintains milk energy output by increasing milk fat content when yield is compromised due to a deficit in energy supply and decreased milk protein content under negative energy balance. Although these tendencies are generally observed, the metabolic pathways involved are sufficiently complex as to preclude the development of an energy balance predictor from first principles (Hanigan et al., 2002). Milk fat:protein ratio was evaluated as an indicator of negative energy balance using monthly test-day milk samples (Heuer et al., 2000; 2001). Although it is clear that milk composition 
varies with energy status, the accuracy of prediction using monthly test-day samples was not impressive.

In the context of automated sampling and inline milk analysis, it is expected that a substantially higher frequency of measurement would be possible and an improvement in accuracy of energy status determination may be possible. To examine the potential of milk composition changes to detect energy status under frequent sampling conditions, we have carried out an exploratory analysis of data from an experiment in which milk composition was measured at each milking. The aims of this study were as follows: 1) to identify which combination of milk measures best describes energy balance; 2) to determine how sensitive the identified combination of measures is to stage of lactation, breed, and parity; and 3) to quantify the accuracy that can be achieved using frequent milk measurements for prediction of breed-parity average energy balance and explore the suitability of such predictions for estimating energy balance of individual cows.

\section{MATERIALS AND METHODS}

\section{Experiment Design and Records}

The data used were collected within a 5-yr experiment conducted from October 1996 to October 2001 at the Danish Cattle Breeders Organization research farm, Ammitsbøl Skovgård. All the procedures involving animals were approved by the Danish Animal Experiments Inspectorate and complied with the Danish Ministry of Justice Law number 382 (June 10, 1987) and Acts 739 (December 6, 1988) and 333 (May 19, 1990) concerning animal experimentation and care of experimental animals.

The design and methods for the production aspects of the experiment were described in detail elsewhere (Nielsen et al., 2003). Briefly, 3 breeds were represented: Danish Holstein, Danish Red, and Jerseys. The design included 2 genetic lines within each breed. For Danish Red and Danish Holstein, the 2 lines were selected solely for milk yield or dual-purpose milk and meat production. The 2 Jersey lines were Danish Jerseys and American Jerseys. A summary of the performance of the different breeds and lines has been presented by Nielsen et al. (2003). Within all levels of genetic structure, cows were equally assigned to 1 of 2 dietary treatments. The cows were studied during consecutive lactations and remained on the same dietary treatment throughout. The cows were housed throughout the year in single tie stalls. Records of 623 lactations from 299 cows were available. The number of lactations in each parity was 269, 226, and 128 for parities 1,2 , and $3+$, respectively.
The cows were fed 1 of 2 TMR ad libitum throughout lactation. The normal energy diet (NTMR) was designed to allow the cows to meet their energy requirements. The low energy diet (LTMR) was designed to limit feed energy supply. The composition of the 2 TMR was fixed irrespective of stage of lactation. The average digestible energy contents of NTMR and LTMR were 13.55 and $12.88 \mathrm{MJ} / \mathrm{kg}$ of DM, respectively. The average CP contents of NTMR and LTMR were 153 and $145 \mathrm{~g} /$ $\mathrm{kg}$ of DM, respectively. Intake was recorded 3 times weekly, as described by Nielsen et al. (2003).

The cows were milked twice daily. Milk yield and milk composition were recorded at each milking. Proportional milk samples taken from each milking were analyzed for fat, protein, and lactose. All animals were weighed on $\mathrm{d} 2,3$, and 8 after calving and then once weekly until 3 mo after calving. From 3 mo after calving to the dry period, they were weighed fortnightly. During the dry period, the cows were weighed once weekly. To minimize the influence from milking and feeding, the cows were weighed at the same time of day. Body condition was scored to the nearest half-unit on the Danish scale (Kristensen, 1986; derived from Lowman et al., 1976) from 1 to 5 on d 2, 14, 28, 42, 56, 84, 112, 168, and 224 after calving. Additionally, BCS was recorded on the day of drying off; 35,21 , and $7 \mathrm{~d}$ before expected calving; and finally, on the day of calving. All BCS were made by the trained personal on the research farm, where the same person made $92 \%$ of the scores. When cows required the attention of a veterinarian, veterinary diagnosis and treatment were recorded. Using the treatment records, periods in which the cow was assumed not healthy were defined according to disease or disorder type (Fourichon et al., 1999; Bareille et al., 2003).

\section{Data Manipulation}

Milk yield, milk fat percentage, and DMI records were checked for outliers according to the procedure used by Friggens et al. (1999). Observations with a residual greater than +5 or less than -5 standard deviations from a cubic spline fit were rejected. Extremely deviant observations, which highly influenced the residual standard deviations, were accounted for by running the spline procedure twice, the second time without the deviant observations identified in the first run. In total, over both splines, $0.4 \%$ of intake records, $0.4 \%$ of milk composition records, and $0.7 \%$ of milk yield observations were rejected. Condition score and BW records for each cow and lactation number were checked for deviant observations by visual inspection relative to DIM. There were $0.6 \%$ of the BCS records and $0.8 \%$ of the BW records rejected. 
All the data used in the subsequent analyses were smoothed data. The smoothing was done using a rolling local regression by the Loess procedure as implemented by SAS (version 8.02, SAS Institute, Cary, NC). The standard deviation of the smoothed data for milk fat percentage was $90.2 \%$ of the standard deviation of the raw data. Similar reductions were found for the other measures. This smoothing was done for 2 reasons: first, there was a need to use rate of change variables, and these are noisy when calculated using unsmoothed data. Second, when using a time series of data from which to make predictions, standard practice is to use smoothed data before interpretation (Friggens and Chagunda, 2005). Thus, the base data relevant to application of these methods were locally smoothed data. Data from the colostrum period (d 0 to 3 of lactation) were excluded from the statistical analyses as were data from after $d 301$ in lactation.

\section{Calculation of Energy Balance}

The classic, and generally accepted, way of calculating energy balance from inputs and outputs includes the milk components. Therefore, for purely statistical reasons, we would expect a strong relationship between milk composition and energy balance. The obvious way of trying to avoid this unwanted correlation was to derive energy balance from measures other than milk measures (EBal; i.e., from changes in body reserves). The EBal can be calculated using changes in $\mathrm{BW}(\Delta \mathrm{BW})$ and BCS $(\Delta \mathrm{CS})$ and the product of BCS and BW $[\Delta(\mathrm{CS}$ $\times \mathrm{BW})]$ combined in the following equation:

$$
\begin{gathered}
\text { EBal }=(\mathrm{a} \times \mathrm{z}-\mathrm{a} \times \mathrm{y} \times \mathrm{k}+\mathrm{y} \times \mathrm{k}) \times \Delta \mathrm{BW} \\
+(\mathrm{b} \times \mathrm{z}-\mathrm{b} \times \mathrm{y} \times \mathrm{k}) \times \Delta(\mathrm{CS} \times \mathrm{BW}) \\
-(\mathrm{b} \times \mathrm{z} \times \text { Gut }-\mathrm{b} \times \mathrm{y} \times \mathrm{k} \times \text { Gut }) \times \Delta \mathrm{CS}
\end{gathered}
$$

where $\mathbf{a}=$ the intercept and $\mathbf{b}=$ slope of the relationship between CS and body lipid content; Gut = gutfill; $\mathbf{k}=$ the protein content of the lipid-free empty body; $\mathbf{y}=$ the energy associated with a change in body protein; and $\mathbf{z}=$ the energy associated with a change in body lipid. The derivation for this equation is given in the appendix.

The component variables of energy balance calculated from measures of change in body reserves are: $\Delta \mathrm{BW}, \Delta \mathrm{CS}$, and $\Delta(\mathrm{CS} \times \mathrm{BW})$. To calculate this $\mathrm{EBal}$, estimates of $a, b$, Gut, $k, y$, and $z$ are required. Coefficients $\mathrm{k}, \mathrm{y}$, and $\mathrm{z}$ can be regarded as universal constants with $\mathrm{k}=0.2224(\mathrm{~kg} / \mathrm{kg}) ; \mathrm{y}=13.5 \mathrm{MJ}$ of effective energy/ $\mathrm{kg}$ of body protein mobilized; $\mathrm{y}=50.0 \mathrm{MJ}$ of effective energy $/ \mathrm{kg}$ of body protein deposited; $\mathrm{z}=39.6 \mathrm{MJ}$ of effective energy $/ \mathrm{kg}$ of body lipid mobilized; and $\mathrm{z}=56.0$
MJ of effective energy/kg of body lipid deposited (Emmans, 1994; Friggens and Ingvartsen, 2002). Because the values of $y$ and $\mathrm{z}$ depend upon whether body protein and lipid are being mobilized or deposited, 3 periods of lactation were defined according to DIM: period $1=0$ to 28 ; period $2=49$ to 70 ; and period $3=112$ to 301 . The first period (P1) represented the period in which both protein and lipid mobilization likely occurs (Cammell et al., 2000). The second period (P2) represented lipid mobilization and possible protein deposition. The third period (P3) represented both lipid deposition and possible protein deposition. It was assumed that the relevant values of $y$ in phases 1 to 3 were $13.5,50.0$, and 50.0, respectively. It was assumed that the relevant values of $\mathrm{z}$ in phases 1 to 3 were 39.6, 39.6, and 56.0, respectively.

Although estimates of $a, b$, and Gut exist (Chilliard et al., 1987; Friggens et al., 2004), they can vary according to factors such as the local diet and local BCS scale used. Also, it cannot be ruled out that these coefficients may be affected by breed and parity.

To avoid introducing bias into the calculation of EBal, especially different biases between breed parity groups, the values of $a, b$, and Gut were estimated within the current data set as follows. First, using initial literature-derived estimates of a, b, and Gut, EBal was calculated, then the association between EBal and milk composition was computed within each breed parity group, using the partial least squares regression (PLS) method described below with an extensive panel of 25 milk measures. This process was then repeated across a biologically feasible range of different estimates of a, $\mathrm{b}$, and Gut by iteration using a grid-search technique to find the estimates of $a, b$, and Gut that gave the lowest prediction error according to cross-validation. The prediction error was measured as the root mean squared error of prediction (RMSEP; normalized with the standard deviation of EBal). The initial estimates of a and b were -0.043 and 0.12 (Friggens et al., 2004), and the initial estimate of Gut used was $6 \times$ (average DMI), which is equivalent to assuming that the DM content of gutfill is $16.7 \%$ (Chilliard et al., 1987). The RMSEP for the PLS equation across all breeds and parities using the initial estimates of $a, b$, and Gut was $3.5 \mathrm{MJ} / \mathrm{d}$; the explained $\mathrm{Y}$ variance (i.e., the variance in EBal) was $95.9 \%$. In the grid search, these initial estimates were allowed to vary between bounds of -0.16 to $0.06,0.06$ to 0.15 , and 2 to 8 for a, b, and Gut/(average DMI), respectively.

Because there were no marked differences between breeds and parities in the optimized values of $a, b$, and Gut, the grid-search procedure was repeated using a data set that contained all breeds and parities. Using the full data set for the optimization minimizes the risk 
Table 1. Correlations among milk measures ${ }^{1}$ and the measures used to calculate energy balance ${ }^{2}$ for parity 2 Danish Holstein cows

\begin{tabular}{|c|c|c|c|c|c|c|c|c|c|c|c|c|c|}
\hline Item & DFC & MY & MFC & MPC & MLC & $\mathrm{mFy}$ & $\mathrm{mPy}$ & mLy & $F: P$ & $\mathrm{~F}: \mathrm{L}$ & P:L & $\operatorname{diff}(\mathrm{CS})$ & $\operatorname{diff}(B w t)$ \\
\hline MFC & -0.018 & -0.347 & & & & & & & & & & & \\
\hline MPC & 0.486 & -0.611 & 0.532 & & & & & & & & & & \\
\hline $\mathrm{mFy}$ & -0.657 & 0.874 & 0.125 & -0.389 & 0.294 & & & & & & & & \\
\hline $\mathrm{mPy}$ & -0.513 & 0.913 & -0.168 & -0.265 & 0.304 & 0.879 & & & & & & & \\
\hline $\mathrm{mLy}$ & -0.614 & 0.989 & -0.363 & -0.621 & 0.483 & 0.860 & 0.900 & & & & & & \\
\hline $\operatorname{diff}(\mathrm{CS})$ & 0.579 & -0.365 & -0.236 & 0.292 & -0.064 & -0.504 & -0.291 & -0.345 & -0.534 & -0.197 & 0.243 & & \\
\hline $\operatorname{diff}(B w t)$ & 0.509 & -0.269 & -0.327 & 0.135 & -0.043 & -0.448 & -0.268 & -0.248 & -0.465 & -0.270 & 0.104 & 0.574 & \\
\hline $\operatorname{diff}(\mathrm{CS} \times \mathrm{Bwt})$ & 0.631 & -0.392 & -0.288 & 0.277 & -0.080 & -0.557 & -0.337 & -0.370 & -0.568 & -0.234 & 0.234 & 0.958 & 0.764 \\
\hline
\end{tabular}

${ }^{1}$ Milk composition measures are as follows: DIM, milk yield (MY), fat content (MFC), protein content (MPC), lactose content (MLC), fat yield $(\mathrm{mFy})$, protein yield $(\mathrm{mPy})$, lactose yield $(\mathrm{mLy})$, fat:protein ratio $(\mathrm{F}: \mathrm{P})$, fat:lactose ratio $(\mathrm{F}: \mathrm{L})$, and protein:lactose ratio $(\mathrm{P}: \mathrm{L})$. Abbreviations starting with "diff" are the current minus the previous value of the milk measure in question. Yield values are in kilograms per day, content values are percentages, and ratios are unitless.

${ }^{2}$ Energy balance measures are the current minus the previous value of the following: condition score [diff(CS)], live weight in kilograms [diff(Bwt)], and the product of condition score and live weight [diff $(\mathrm{CS} \times \mathrm{Bwt})]$.

of overfitting. The resulting optimized values chosen for calculating EBal were as follows: $a=0.05 ; b=0.10$; and Gut $=7$. The RMSEP of the PLS across all breeds and parities using these values was $3.1 \mathrm{MJ} / \mathrm{d}$; the explained Y variance was $96.1 \%$. Once the PLS model reduction described in the next section was done, we again compared the reduced model equation based either on the initial values of $a, b$, and Gut or on the optimized values. The RMSEP and explained Y variance using the literature and optimized values were as follows (MJ/d, \%): 4.4, 93.6 and 3.7, 94.4, respectively. Thus, there is no empirical evidence that this optimization procedure resulted in an overfit with respect to relating milk composition to EBal.

\section{Statistical Analysis}

Because there were significant correlations between milk measures (Table 1), principal components analysis (PCA) was used to explore the relationships between milk measures and combinations thereof through lactation. In this exploratory analysis, the milk measures included were as follows: milk yield (MY), fat content (MFC), protein content (MPC), lactose content (MLC), fat yield ( $\mathbf{m F y}$ ), protein yield ( $\mathbf{m P y})$, lactose yield $(\mathbf{m L y})$, fat:protein ratio $(\mathbf{F}: \mathbf{P})$, fat:lactose ratio $(\mathbf{F}: \mathbf{L})$, and protein:lactose ratio (P:L), together with DIM. The yield measures were in kilograms per day, the content measures were in percentages, and the ratios are unitless.

The relationship between EBal and milk measures was quantified using PLS as implemented by LatentiX, version 1.05beta (www.latentix.com). To address the issue of the extent to which milk measures can describe the lactation curve of energy balance and the differences between breeds and parities, PLS was done using group mean data. For each day in lactation, the withinbreed and parity average EBal and average milk measures were used. To assess the ability of milk measures to predict the energy balance of individual animals, the predictive ability of the group mean-derived equation relating milk measures to EBal was assessed on individual cow data by PLS prediction. Further PLS was done directly using the individual cow data.

When viewed as changes in body energy reserves, energy balance is the net effect of 4 biological processes: deposition or mobilization of body protein and deposition or mobilization of body lipid (see appendix). Because there is no a priori reason for the relationship between energy balance and milk composition to be the same for these 4 processes, we examined this relationship by PLS for the 3 different periods in lactation described in the preceding section. In addition, we quantified the PLS fit for a combined data set including all days in lactation (from $d 3$ to 301). The goodness of fit of PLS models derived from data in 1 period was assessed in terms of the prediction error when applied to the other periods.

In all the PLS models run during this study, X-data (milk composition variables) were mean-centered and scaled to have equal variance, and Y-data (EBal) were mean-centered. The PLS models were initially run including 25 combinations of milk measures to allow for a range of nonlinear effects. These combinations were as follows: DIM; DIM raised to the powers 2, 3, and 4 (DIM_2, DIM_3, DIM_4); MY; MFC; MPC; MLC; mFy; mPy; mLy; F:P; F:L; P:L; and milk yield:lactose ratio (MY:L), together with 10 "diff()" variables. These are 
the current minus the previous value of the milk measure in question $[\operatorname{diff}(\mathrm{MY}), \operatorname{diff}(\mathrm{F}), \operatorname{diff}(\mathrm{P}), \operatorname{diff}(\mathrm{L})$, $\operatorname{diff}(\mathrm{F}: \mathrm{P}), \quad \operatorname{diff}(\mathrm{F}: \mathrm{L}), \quad \operatorname{diff}(\mathrm{P}: \mathrm{L}), \quad \operatorname{diff}(\mathrm{mFy}), \quad \operatorname{diff}(\mathrm{mPy})$, $\operatorname{diff}(\mathrm{mLy})]$. Smoothed values of all variables were available for all days in lactation. Although MY and milk composition were measured every day in lactation, BW and BCS were measured less frequently; thus, there was a risk of inflating goodness-of-fit statistics by including smoothed values not associated with real observations when fitting the PLS models to whole lactation data. This was avoided by including only 1 value per lactation week (approximating the BW measurement frequency) in the PLS models. Model validation was carried out by cross-validation using 4 segments. The percentage of variance in EBal explained by the PLS model in cross-validation on the same data set was used to indicate the goodness of fit of the PLS models. The RMSEP from cross-validation on the same data set and from validation on the other period datasets was used to assess the predictive ability of the PLS models. The RMSEP can be interpreted as a proxy for the expected standard deviation of the differences between predicted and actual values of EBal when using the PLS model to predict EBal from similar milk composition datasets.

Model reduction was carried out in 3 phases: first, by choosing, in each period of lactation, the 5 milk composition variables that explained the most variance in EBal (principal variables; Höskuldsson, 1994); second, by creating a common combined set of variables across all periods; and third, by manually reducing and substituting alternative variables for the model chosen variables. This last step was carried out using biological knowledge of the relationships between milk composition variables in conjunction with the results of the PCA. The benefits of substituting 1 variable for another were judged from the explained variance and RMSEP values of the resulting PLS models.

\section{RESULTS}

\section{Exploratory Data Analysis}

The relationships between milk components and DIM are shown in Figure 1 for 3 different breeds (Danish Red; Holstein-Friesian; Jersey) in parity 1 . The equivalent data for parity 2 are shown in Figure 2. Because the data for parity 3 were similar to parity 2 , these are not shown. Expressing the milk components as total yields rather than as percentages reduces, to some degree, the complexity of the lactation curves (Figures 1 and 2), and, thus, the component yields were included in the exploratory analyses. Likewise, the milk component ratios (Figures 1 and 2) were included. The variation among these milk components was characterized using PCA. Using only the milk component variables (MY,
MFC, MPC, MLC, mFy, mPy, mLy, F:P, F:L and P:L), it was clear that there were systematic patterns in the principal component scores due to breed, parity, and DIM (Figure 3). Given the similarity among the breed curves, it seemed likely that variables quantifying the rate of change in milk components might better account for the observed variation. Thus, these variables ("diff" variables) were calculated and PCA carried out on them. No significant differences among breeds were found in the first principal component (PC1) when using the "diff" variables. The same was the case for parity differences. Therefore, these variables were included together with the first set of milk component variables in a PCA. There were no clear groupings of variables evident in the first principal component, although most of the yield-containing variables had a negative loading (Table 2). Likewise, in the second and higher principal components, there were no clear loading patterns. This suggested that no 1 or 2 milk variables alone were likely to provide strong predictors of factors affecting milk composition.

Given the results of this exploratory PCA, it was decided to proceed with the development of a predictive model for EBal using the full panel of milk variables.

\section{Relationship Between Energy Balance and Milk Composition Using Group Means Data}

Using group means data, an extremely high proportion (96\% for model 1, Table 3) of the variability in EBal could be explained by the PLS model. Within lactation periods $\mathrm{P} 1, \mathrm{P} 2$, and $\mathrm{P} 3$, the prediction errors for $\mathrm{EBal}$ in the same period were $4.5,1.7$, and $3.1 \mathrm{MJ} / \mathrm{d}$, respectively (average EBal values in P1, P2 and P3 were -30.5, -1.9 , and 17.5 MJ/d, respectively). Yet, the PLS models derived in 1 period had low predictive ability when applied to other lactation periods (e.g., when model 2, derived in P1, was applied to data for P2, the RMSEP was $194.3 \mathrm{MJ} / \mathrm{d}$ ). In contrast, the PLS model derived from the whole data set had a high predictive ability when applied to particular periods, deviating from the within-period RMSEP values by, on average, $0.13 \mathrm{MJ} /$ d (model 1, Table 3).

Model reduction, in each of the period models, to include only the 5 milk composition variables that explained the most variance in EBal actually increased the goodness of fit of the PLS and reduced the prediction error within the same periods (models 6,7 , and 8; Table 3). It improved the prediction error when applied to data from other periods in 4 out of the 6 cases. The same model reduction when using the whole data set (model 5) resulted in a slight decline in goodness of fit from 96.1 to $94 \%$ (Table 3). As a starting point for a reduced model that was robust across the different peri- 

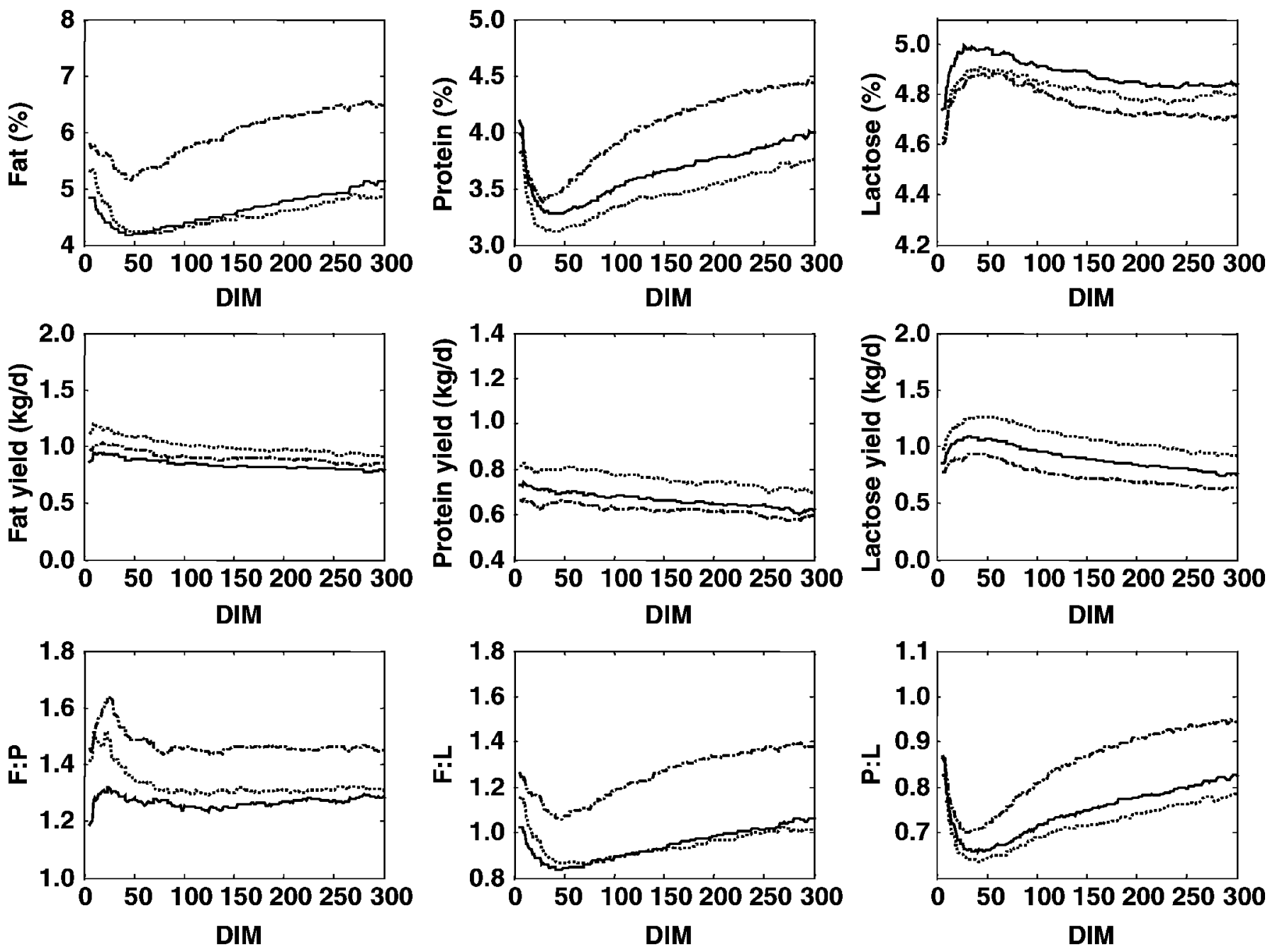

Figure 1. Average milk composition changes relative to DIM for parity 1 cows of the Danish Red (solid lines), Holstein-Friesian (dotted lines), and Jersey (stippled lines) breeds. The top 3 graphs show milk composition (\%), the middle 3 graphs show milk component yields $(\mathrm{kg} / \mathrm{d})$, and the bottom 3 graphs show milk component ratios. $\mathrm{F}: \mathrm{P}=$ fat:protein ratio; $\mathrm{F}: \mathrm{L}$ = fat:lactose ratio; $\mathrm{P}: \mathrm{L}=$ protein:lactose ratio.

ods, the variables identified (listed in Table 4) in each of the 3-period, 5 -variable models were combined to give an 11-variable pool. This pool was used to generate models for the different periods and the all-lactation data set (models 9 to 12). As might be expected, the goodness of fit and predictive ability of these 11-variable models were intermediate between those of the full 25variable models (models 1 to 4 ) and those of the 5variable models (models 5 to 8 ). The 11 milk composition variables included in this start point for further model reduction were as follows: DIM, $\mathrm{DIM}^{2}$, fat percentage, lactose percentage, protein yield, fat:protein ratio, milk yield:lactose ratio, change in lactose percentage, change in fat:protein ratio, change in F:L ratio, and change in protein yield.

Removing the variables milk yield:lactose ratio and $\mathrm{DIM}^{2}$ did not change the goodness of fit (model 13, Table
3). Likewise, removing $\mathrm{mPy}$ and change in $\mathrm{mPy}$ had a negligible effect, as did removal of change in lactose percentage. Thus, a model with only 6 variables (model 15) explained $94.0 \%$ of the variation in $\mathrm{EBal}$, which compares well with the $96.1 \%$ explained by the full model with 25 variables (model 1). Given that both fat percentage and the F:P ratio remained in the model, removal of fat percentage was assessed in model 16 . This caused a 1\% drop in explained variance, the largest drop for removal of any single variable removed thus far. An alternative removal investigated was removing the remaining lactose-containing variables [i.e., lactose percentage and change in F:L ratio (model 17)]. This caused a $1 \%$ drop in explained variance but resulted in a model with only 5 variables based on milk measures of fat, protein, and milk yield. The addition of the variable change in $\mathrm{mPy}$ increased the explained variance to 

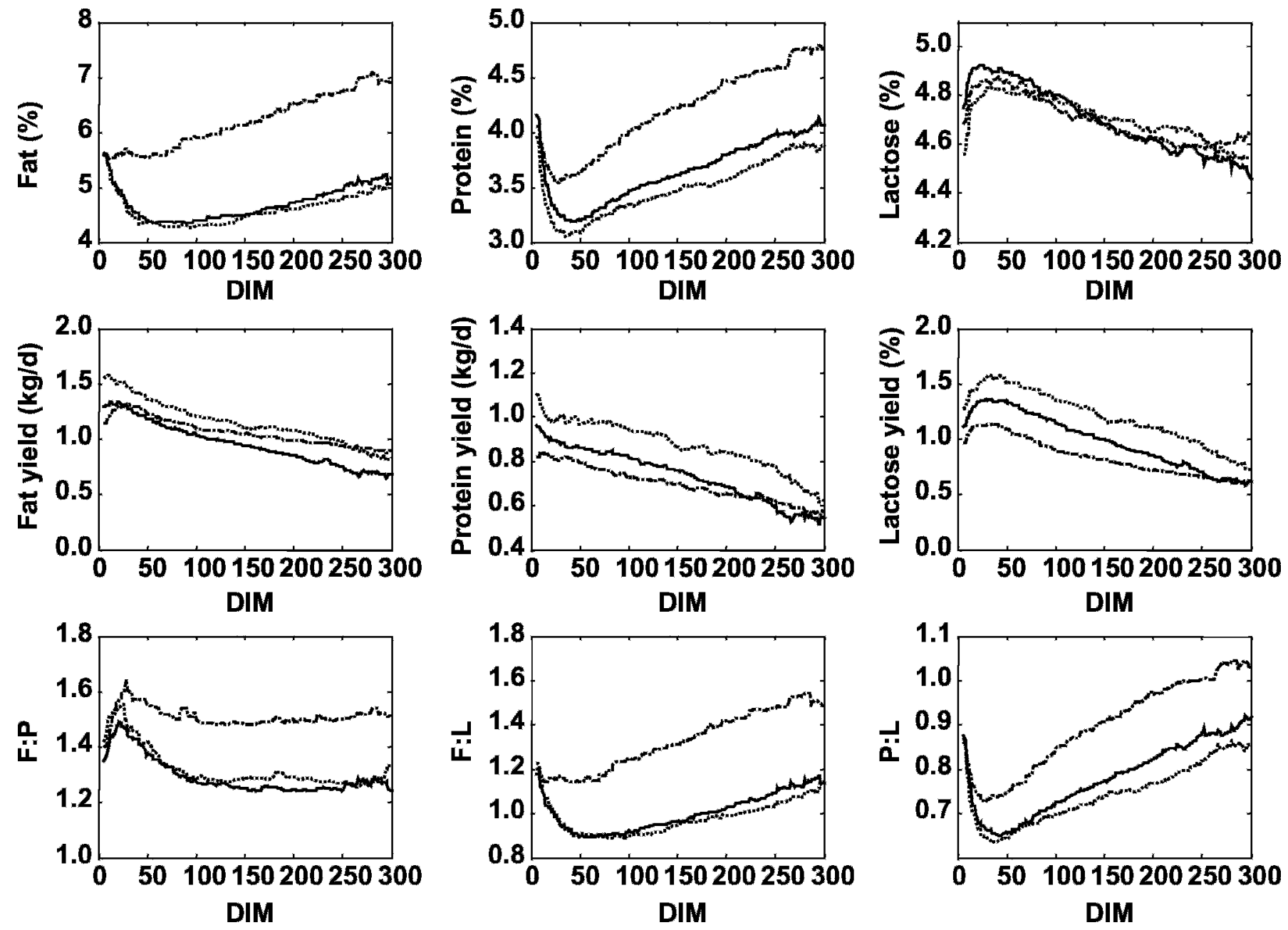

Figure 2. Average milk composition changes relative to DIM for parity 2 cows of the Danish Red (solid lines), Holstein-Friesian (dotted lines), and Jersey (stippled lines) breeds. The top 3 graphs show milk composition (\%), the middle 3 graphs show milk component yields $(\mathrm{kg} / \mathrm{d})$, and the bottom 3 graphs show milk component ratios. F:P = fat:protein ratio; F:L = fat:lactose ratio; P:L = protein:lactose ratio.

94.4\% without involving an additional measure (model 18). This model had a prediction error of $3.7 \mathrm{MJ} / \mathrm{d}$; the full 25-variable model had a prediction error of 3.1 $\mathrm{MJ} / \mathrm{d}$.

For comparison, 2 further models were evaluated, the reduced model minus DIM (model 19, Table 3) and a model containing all nonlactose variables (model 20, Table 3). The removal of DIM (an available measure on-farm but not necessarily a biologically relevant one) increased the prediction error from 3.7 (model 18) to $4.5 \mathrm{MJ} / \mathrm{d}$ and decreased the explained variance from 94.4 to $91.9 \%$. The effect of removing DIM from the other models (models 1, 9, 13, and 20) was similar (results not shown). Going to the other extreme, including all combinations of milk measures in the reduced model [i.e., all nonlactose variables (and DIM)], resulted in a 13-variable model that performed slightly better than the 6 -variable model 18 . This full nonlactose variable set (model 20) was used to derive within-period models (21 to 23). The prediction errors when applied to other periods were substantially better than the equivalent prediction errors from the equivalent full 25 -variable models (2 to 4 ) in 5 out of 6 cases.

Actual vs. predicted EBal values from model 18 are shown in Figure 4. Predicted and actual EBal values relative to DIM are shown in Figure 5, for Danish Holstein in parities 1 and 2 . The prediction equations derived using the 6 -variable model 18 and model 20, the nonlactose variables, are presented in Table 5.

\section{Relationship Between Energy Balance and Milk Composition Using Individual Data}

The reduced PLS model 18 was used to generate predicted EBal values for individual cow data. The predic- 


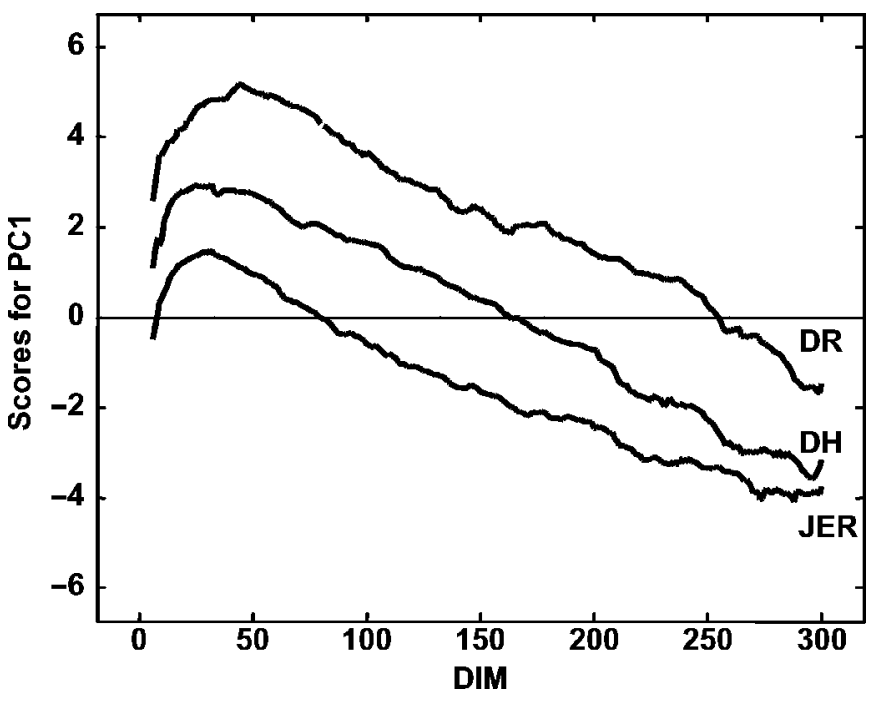

Figure 3. Scores for the first principal component (PC1) from a principal components analysis of 10 variables describing milk composition, milk component yields, and the ratios between them but not including the rates of change in these variables. Scores are plotted relative to DIM for Danish Red (DR), Danish Holstein (DH), and Jersey cows (JER). tion error (RMSEP) for the use of the group meansderived model on individual data was $22.2 \mathrm{MJ} / \mathrm{d}$. Examples of individual plots of predicted and actual EBal are given in Figure 6. To elucidate possible sources of this substantially increased prediction error (relative to the prediction error of cross-validation for group means data of 3.7), we examined the distribution of the residuals (actual - predicted) according to breed, parity, and period. In addition, we examined whether the prediction error could be reduced by using models that contained more variables.

There were no significant differences between breeds in the means and distributions of residuals when comparing actual and predicted EBal values using model 18 on individual data. The same applied when comparing the residuals by parity and by period and all combinations thereof. There were time trends in the average residual (Figure 7) and in the standard deviation of residuals, indicating that the ability of model 18 to predict individual EBal was lowest in very early lactation.

One possibility is that the model reduction that was appropriate for group means data (and resulted in model 18) may represent an oversimplification when the prediction is at the level of individual EBal values.

Table 2. The relationships among milk composition measures ${ }^{1}$ expressed as loadings in a principal components analysis

\begin{tabular}{|c|c|c|c|c|c|c|c|c|}
\hline \multirow[b]{2}{*}{ Item } & \multicolumn{8}{|c|}{ Principal component } \\
\hline & 1 & 2 & 3 & 4 & 5 & 6 & 7 & 8 \\
\hline Variation explained $^{2}$ & 39.5 & 69.1 & 80.9 & 88.1 & 93.5 & 96.9 & 98.4 & 99.2 \\
\hline DIM & 0.28 & -0.07 & 0.19 & -0.17 & 0.03 & 0.30 & -0.56 & -0.12 \\
\hline MY & -0.27 & 0.22 & -0.05 & -0.08 & -0.23 & 0.13 & -0.11 & 0.00 \\
\hline MFC & 0.15 & -0.27 & -0.38 & 0.03 & -0.07 & -0.06 & -0.10 & -0.02 \\
\hline MPC & 0.22 & -0.29 & -0.12 & 0.02 & -0.04 & 0.01 & -0.33 & -0.06 \\
\hline MLC & -0.14 & 0.10 & -0.14 & 0.48 & 0.21 & -0.58 & -0.51 & -0.15 \\
\hline $\mathrm{mFy}$ & -0.25 & 0.07 & -0.34 & -0.09 & -0.34 & 0.07 & -0.09 & -0.03 \\
\hline $\mathrm{mPy}$ & -0.28 & 0.14 & -0.10 & -0.10 & -0.38 & 0.15 & -0.30 & -0.02 \\
\hline mLy & -0.27 & 0.22 & -0.06 & -0.03 & -0.20 & 0.07 & -0.14 & -0.02 \\
\hline$F: P$ & -0.02 & -0.13 & -0.58 & 0.01 & -0.05 & -0.13 & 0.30 & 0.04 \\
\hline $\mathrm{F}: \mathrm{L}$ & 0.17 & -0.27 & -0.34 & -0.06 & -0.11 & 0.05 & -0.01 & 0.01 \\
\hline $\mathrm{P}: \mathrm{L}$ & 0.23 & -0.28 & -0.07 & -0.11 & -0.09 & 0.16 & -0.14 & -0.02 \\
\hline $\operatorname{diff(MY)}$ & -0.25 & -0.26 & 0.04 & 0.12 & 0.07 & 0.14 & 0.04 & -0.31 \\
\hline $\operatorname{diff}(F)$ & 0.20 & -0.09 & 0.24 & 0.28 & -0.53 & -0.18 & 0.02 & 0.31 \\
\hline $\operatorname{diff}(\mathrm{P})$ & 0.24 & 0.27 & -0.13 & 0.13 & 0.01 & 0.10 & -0.05 & 0.19 \\
\hline $\operatorname{diff}(\mathrm{L})$ & -0.24 & -0.26 & 0.06 & -0.04 & 0.10 & -0.04 & -0.17 & 0.80 \\
\hline $\operatorname{diff}(F: P)$ & -0.15 & -0.30 & 0.23 & -0.08 & -0.21 & -0.24 & 0.04 & -0.12 \\
\hline $\operatorname{diff}(\mathrm{F}: \mathrm{L})$ & 0.27 & 0.06 & 0.14 & 0.22 & -0.44 & -0.11 & 0.14 & -0.18 \\
\hline $\operatorname{diff}(P: L)$ & 0.24 & 0.27 & -0.12 & 0.10 & 0.00 & 0.08 & 0.01 & -0.01 \\
\hline $\operatorname{diff}(\mathrm{mFy})$ & -0.18 & -0.29 & 0.17 & 0.23 & -0.15 & 0.07 & 0.06 & -0.12 \\
\hline $\operatorname{diff(mPy)}$ & -0.06 & -0.03 & -0.08 & 0.68 & 0.08 & 0.56 & 0.04 & 0.10 \\
\hline $\operatorname{diff}(m L y)$ & -0.25 & -0.27 & 0.05 & 0.07 & 0.08 & 0.12 & 0.02 & -0.14 \\
\hline
\end{tabular}

\footnotetext{
${ }^{1}$ Milk composition variables are indicated by the following: DIM, milk yield (MY), fat content (MFC), protein content (MPC), lactose content (MLC), fat yield ( $\mathrm{mFy}$ ), protein yield (mPy), lactose yield (mLy), fat:protein ratio (F:P), fat lactose ratio (F:L), and protein:lactose ratio (P:L). Variable abbreviations starting with "diff" are the current minus the previous value of the milk measure in question. Yield values are in kilograms per day, content values are percentages, and ratios are unitless. The measures used were group mean averages for each DIM.

${ }^{2}$ Cumulative percentage of variation explained with increasing number of principal components included.
} 
Table 3. Prediction errors and goodness of fit for partial least squares (PLS) models relating milk composition to energy balance using group mean data

\begin{tabular}{|c|c|c|c|c|c|c|c|c|}
\hline \multirow[b]{2}{*}{ Model type } & \multirow{2}{*}{$\begin{array}{l}\text { Model } \\
\text { no. }^{1}\end{array}$} & \multirow{2}{*}{$\begin{array}{c}\text { PLS } \\
\text { derived } \\
\text { using } \\
\text { data set }^{2}\end{array}$} & \multicolumn{4}{|c|}{$\begin{array}{l}\text { Prediction error obtained by } \\
\text { validation using data } \text { set }^{3}\end{array}$} & \multirow{2}{*}{$\begin{array}{c}\text { Explained } \\
\text { Y-variance }\end{array}$} & \multirow{2}{*}{$\begin{array}{l}\text { Number of } \\
\text { PC } \text { chosen }^{5}\end{array}$} \\
\hline & & & All & $\mathrm{P} 1$ & P2 & P3 & & \\
\hline \multirow[t]{4}{*}{ All variables } & 1 & All & 3.1 & 4.7 & 2.1 & 2.2 & 96.1 & 12 \\
\hline & 2 & P1 & $3,245.0$ & 4.5 & 194.3 & $3,487.0$ & 84.9 & 5 \\
\hline & 3 & P2 & 458.5 & 12.8 & 1.7 & 493.3 & 83.0 & 2 \\
\hline & 4 & P3 & 9.9 & 30.2 & 6.9 & 3.1 & 77.4 & 10 \\
\hline \multirow[t]{4}{*}{ PV 1 to 5} & 5 & All & 3.9 & 6.4 & 2.8 & 3.6 & 94.0 & 3 \\
\hline & 6 & $\mathrm{P} 1$ & 33.6 & 4.5 & 14.3 & 36.3 & 85.3 & 5 \\
\hline & 7 & P2 & 30.8 & 12.4 & 1.5 & 32.8 & 86.9 & 5 \\
\hline & 8 & P3 & 13.1 & 41.9 & 8.5 & 2.4 & 86.9 & 5 \\
\hline \multirow[t]{4}{*}{ PV combined } & 9 & All & 3.4 & 6.3 & 1.9 & 2.3 & 95.2 & 10 \\
\hline & 10 & $\mathrm{P} 1$ & 623.3 & 4.4 & 41.4 & 677.4 & 85.8 & 5 \\
\hline & 11 & P2 & 72.8 & 17.3 & 1.6 & 78.3 & 84.8 & 6 \\
\hline & 12 & P3 & 8.9 & 25.5 & 11.6 & 2.8 & 81.6 & 1 \\
\hline \multirow[t]{7}{*}{ Model reduction } & 13 & All & 3.7 & 6.7 & 2.8 & 2.6 & 94.4 & 7 \\
\hline & 14 & All & 3.8 & 6.8 & 2.3 & 2.9 & 94.1 & 7 \\
\hline & 15 & All & 3.9 & 6.9 & 2.3 & 3.1 & 94.0 & 6 \\
\hline & 16 & All & 4.0 & 7.4 & 2.2 & 3.5 & 93.4 & 3 \\
\hline & 17 & All & 4.1 & 6.2 & 3.6 & 3.9 & 93.4 & 5 \\
\hline & 18 & All & 3.7 & 5.7 & 3.3 & 3.3 & 94.4 & 6 \\
\hline & 19 & All & 4.5 & 6.3 & 5.4 & 3.7 & 91.9 & 5 \\
\hline \multirow[t]{4}{*}{ Nonlactose } & 20 & All & 3.6 & 4.9 & 2.8 & 3.3 & 94.9 & 11 \\
\hline & 21 & $\mathrm{P} 1$ & 137.4 & 5.2 & 38.9 & 234.7 & 80.2 & 7 \\
\hline & 22 & P2 & 16.2 & 8.8 & 1.6 & 26.5 & 84.5 & 3 \\
\hline & 23 & P3 & 11.5 & 16.9 & 10.1 & 3.3 & 75.0 & 7 \\
\hline
\end{tabular}

${ }^{1}$ The milk composition variables included in each model are listed in Table 4 . Models 1 to 4 include all milk composition measures used; models 5 to 8 include only the 5 principal variables that account for the most variation in energy balance in each data set; models 9 to 12 include all the principal variables found in models 6 to 8, models 13 to 19 deal with further model reduction, and models 20 to 23 contain all nonlactose variables.

${ }^{2}$ Four data sets were used: days from calving 3 to 28 (P1), days from calving 49 to 70 (P2), days from calving 112 to 301 (P3), and all days from calving.

${ }^{3}$ Prediction errors are the root mean square error of prediction (RMSEP). Values in bold are from crossvalidation on the same data set from which the model was derived. The non-bold values are from validation on data sets other than the one from which the model was derived.

${ }^{4}$ The percentage of variance in energy balance explained by the PLS model in cross-validation on the same data set.

${ }^{5}$ The number of principal components (PC) chosen as giving the minimum RMSEP estimated by crossvalidation.

Therefore, we calculated the prediction errors when using more complex models to predict individual EBal. Model 20 is an elaboration of model 18, including all the nonlactose variables; the prediction error when using this model on individual data was $22.1 \mathrm{MJ} / \mathrm{d}$. Model 1 is an elaboration of model 20 , including all 25 variables; the prediction error when using this model on individual data was $20.4 \mathrm{MJ} / \mathrm{d}$. Thus, it did not seem that the low prediction error obtained with individual data was due to model oversimplification. A new PLS model using all 25 variables was derived but this time from the individual data (in contrast to model 1, which was derived from group mean data). The prediction error of this model by cross-validation (i.e., validation on the same data set from which the model was derived) was $17.3 \mathrm{MJ} / \mathrm{d}$. This represented the best possible pre- diction error that could be achieved using the individual data with these milk measures and EBal values. To check the dependence of this result on the variables used for deriving energy balance values, the predictions of individual energy balance values from model 18 were compared with both actual energy balance calculated from BW and BCS (EBal) as described previously and actual energy balance calculated from energy intake minus energy outputs (EBinout) as described by Friggens et al. (2007). The $\mathrm{R}^{2}$ value for the regression of EBal on predicted for individuals was $39 \%$. The $\mathrm{R}^{2}$ value for the regression of EBinout on predicted for individuals was $50 \%$.

\section{DISCUSSION}

The purpose of this study was to find out whether there was a stable relationship between energy balance 


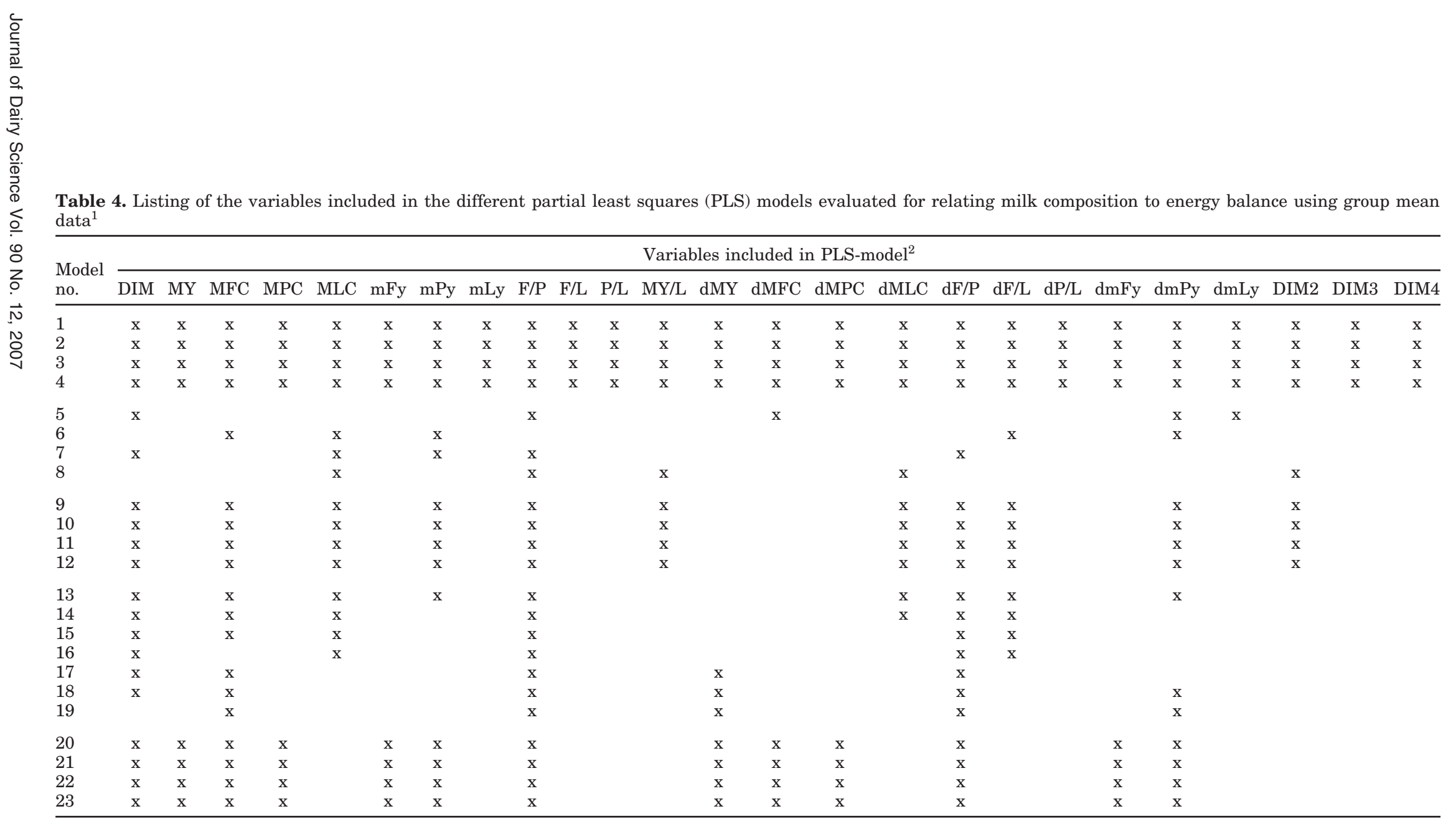

${ }^{1}$ Prediction errors and goodness of fit for these models are given in Table 3 .

${ }^{2}$ Milk composition variables are indicated by DIM, milk yield (MY), fat content (MFC), protein content (MPC), lactose content (MLC), fat yield (mFy), protein yield (mPy), lactose yield (mLy), fat:protein ratio (F/P), fat:lactose ratio (F/L), protein:lactose ratio (P/L), and milk yield:lactose ratio (MY/L). Variable abbreviations starting with "d" are the current minus the previous value of the milk measure in question; DIM2, DIM3, and DIM4 are DIM raised to the powers 2, 3, and 4, respectively. Yield values are in $\mathrm{kg} / \mathrm{d}$; content values are in \%, and ratios are unitless. 


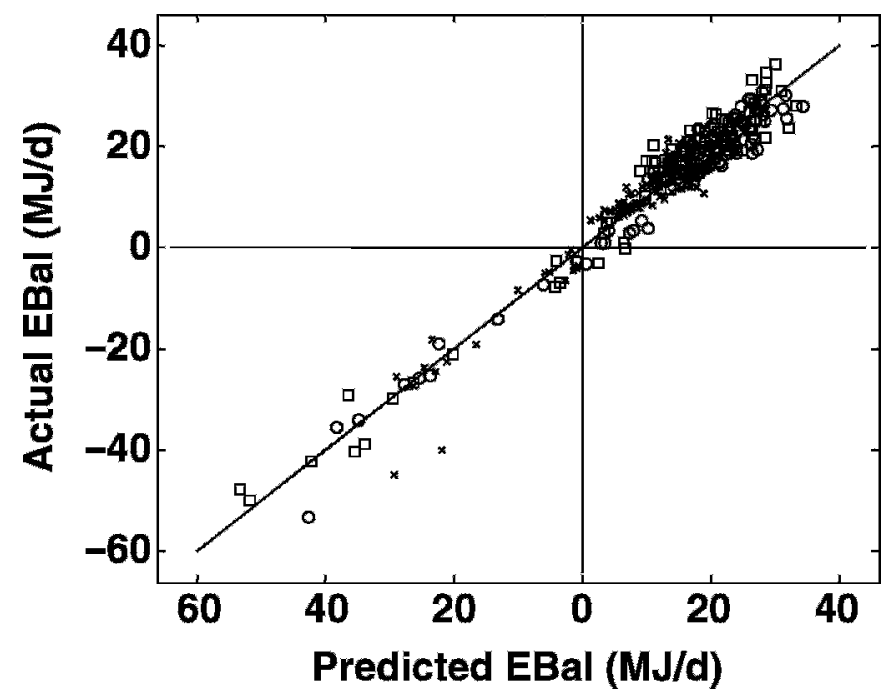

Figure 4. Actual vs. predicted energy balance (EBal) based on group mean data using partial least squares regression model 18 for Danish Red $(\bigcirc)$, Danish Holstein $(\square)$, and Jersey $(\times)$ cows in all parities. Actual energy balance was calculated from changes in BW and BCS.

and milk composition measures and, if so, how accurately could energy balance be predicted. Using the daily average milk composition for breed-parity groups, the same predictive equation based only on milk measures and DIM was able to predict energy balance regardless of whether the cows in question where Danish Reds, Danish Holsteins, or Jerseys. The same applied to cows in parities 1,2 , and $3+$. This occurred despite the substantial differences between breeds and parities in MY and milk composition (Figures 1 and 2) that were typically reported (Wood, 1980; Dillon et al., 2003). The reason that breed- and parity-specific equations were not necessary was because the PLS regression analyses included the rate of change in milk components ("diff" variables) as well as absolute milk composition variables. The "diff" variables were not significantly affected by breed and parity.

The percentage of variance in energy balance explained by the PLS models was very high: $96.1 \%$ for the full model 1 and $94.4 \%$ for the reduced model 18 (Table 3). This was higher than the equivalent measures of goodness of fit reported previously (Heuer et al., 2000, 2001). In early lactation, Heuer et al. (2001) reported an average prediction error of $9.6 \mathrm{MJ} / \mathrm{d}$; using model 18, the average error of prediction of EBal was $3.7 \mathrm{MJ} / \mathrm{d}$ (RMSEP, Table 3). In early lactation, in which the average EBal was -30.5 , this corresponds to an uncertainty of prediction of approximately $12 \%$. This accuracy was achieved despite deriving energy balance measurements not from input-output calculations but from changes in BW and BCS. At first sight, relating
A

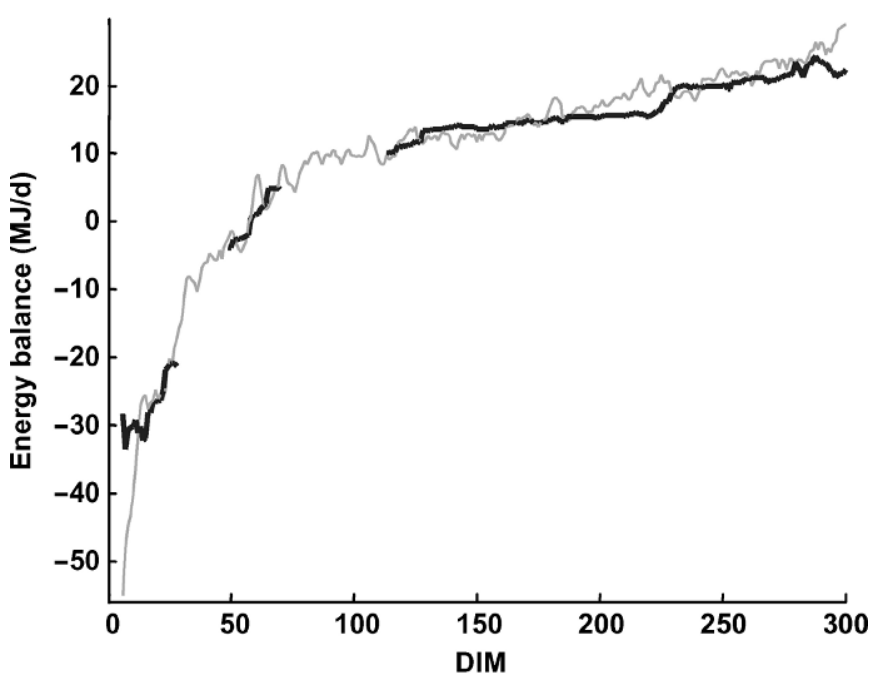

B

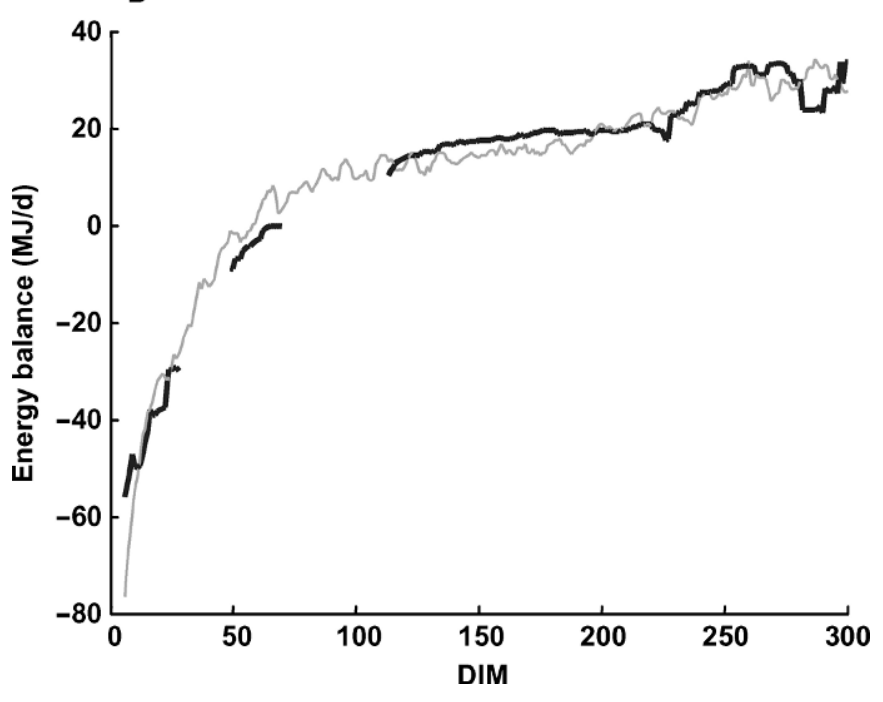

Figure 5. Predicted (thin line) and actual (thick line) energy balance based on group mean data using partial least squares regression model 18 for Danish Holsteins in A) parity 1 and B) parity 2 relative to DIM. Actual energy balance was calculated from changes in BW and BCS.

energy balance to milk composition seems like a trivial regression task given a decent data set; however, it is methodologically difficult for many reasons. First, the traditional input-output method of calculating EBinout includes MY and milk composition, and, thus, there is the risk of generating spurious correlations and inflating goodness-of-fit statistics by having the same variables on both sides of the regression equation between EBinout and milk composition. For this reason, we chose to calculate energy balance from changes in BW and BCS (EBal), thus trying to avoid this problem.

A second issue is that, irrespective of the method chosen, an unseemly number of constants are used in 
Table 5. The regression coefficients for predicting energy balance from milk composition variables derived using partial least squares regression with model reduction

\begin{tabular}{|c|c|c|c|c|c|c|c|c|c|c|c|c|c|}
\hline Intercept & \multicolumn{13}{|c|}{ Regression coefficients $^{1}$} \\
\hline $\begin{array}{l}\text { Model } 20 \\
83.6 \\
\text { Model } 18\end{array}$ & 0.070 & -1.54 & 11.5 & -17.9 & -57.9 & 128.7 & -61.7 & -38.1 & 212.6 & 82.3 & -661.4 & 784.7 & 34.4 \\
\hline 82.4 & 0.065 & & 5.00 & & & & -80.5 & -94.4 & & & & $1,365.8$ & 200.4 \\
\hline
\end{tabular}

${ }^{1}$ Milk composition variables are indicated by: DIM, milk yield (MY), fat content (MFC), protein content (MPC), fat yield (mFy), protein yield ( $\mathrm{mPy}$ ), and fat:protein ratio (F:P). Variable abbreviations starting with "diff" are the current minus the previous value of the milk measure in question. Yield values are in kilograms per day, content values are percentages, and ratios are unitless.

the calculation of energy balance, and some of these are not well determined in any given case. Thus, any energy balance calculated is likely to deviate to differing extents from the true energy balance under different conditions (production levels, lactation stages, diets; Ellis et al., 2006). The extent to which milk components can predict energy balance will depend to some degree on our estimates of these constants. In the case of EBal, the constant with the greatest uncertainty attached is the one that converts BCS to body fatness ( $\mathrm{g}$ of lipid/g of empty BW), because this is dependent on the BCS scale being used. We chose to estimate this, and the constant for gutfill, within the PLS analysis by iteration with different values of these constants. The values chosen for the constants were those that gave the lowest validated prediction error in the full PLS model within biologically feasible bounds for the constant values. By this procedure, which is analogous to that used in residual feed intake analyses (Veerkamp et al., 1995; Luiting, 1999), we attempted to minimize bias due to the energy balance calculation method.

There are many factors which may be expected to have increased the goodness of fit. Our study was based on daily measurements of milk composition, rather than fortnightly or monthly measures. Further, we took advantage of the opportunity afforded by frequent measurements to smooth the milk composition data before the multivariate analysis. This would be the normal situation in any practical application in which frequent measurements are made and is important for being able to derive useable "diff" variables. Both of these factors would provide a major benefit in terms of increasing the goodness of fit of energy balance predictions.

The very high percentage of variance explained and the correspondingly low prediction error obtained using group means data (Figure 5) clearly indicated that there was a stable, biologically based relationship between energy balance and milk composition. The finding that, within the PLS models, DIM only accounted for $2 \%$ of the explained variance in EBal provides further support for this relationship. The use of group means data provided a way to establish this relationship without having to account for all possible differences among individuals. From the point of view of using predicted energy balance as a nutritional diagnostic tool, there would be clear benefits of being able to predict the energy balance of individual cows. When we used the group meansderived equations to predict individual cow energy balance, there was a substantial increase in the prediction error (from 3.7 to $22.2 \mathrm{MJ} / \mathrm{d}$ ), indicating that a significant proportion of the variation among individuals was not being captured by the prediction equation.

There were no clear biases in the residuals (actual minus predicted) due to factors such as breed and parity, although there was a trend relative to DIM (Figure 7). This finding supports the rationale for developing lactation period-specific models as shown in Table 3. Smaller prediction errors were obtained in early lactation when using a model developed on early lactation data (period 1) than when using a whole lactation model. Nonetheless, with both group means and individual data, this low fit of the whole lactation model in early lactation was relatively small with the possible exception of the very first days in lactation.

The unexplained variance when predicting individual energy balance could be due to factors that affect milk composition but were ignored in this study. For example, there is genetic variation within breeds in milk composition and in propensity to mobilize body energy (Coffey et al., 2001) that could generate individual differences in the relationship between milk components and energy balance. It could be that there is significant between-animal variation in the coefficients used to calculate EBal. In particular, the factor relating DMI to gutfill and to a lesser extent the relationship between BCS and body fatness could vary among individuals. As a means to see if this was a major source of the unexplained variance, we compared the $R^{2}$ of a regression of PLS predicted energy balance on EBal with the $R^{2}$ of the same regression, but on EBinout. The $\mathrm{R}^{2}$ values for EBal and EBinout were 39 and 50\%, 

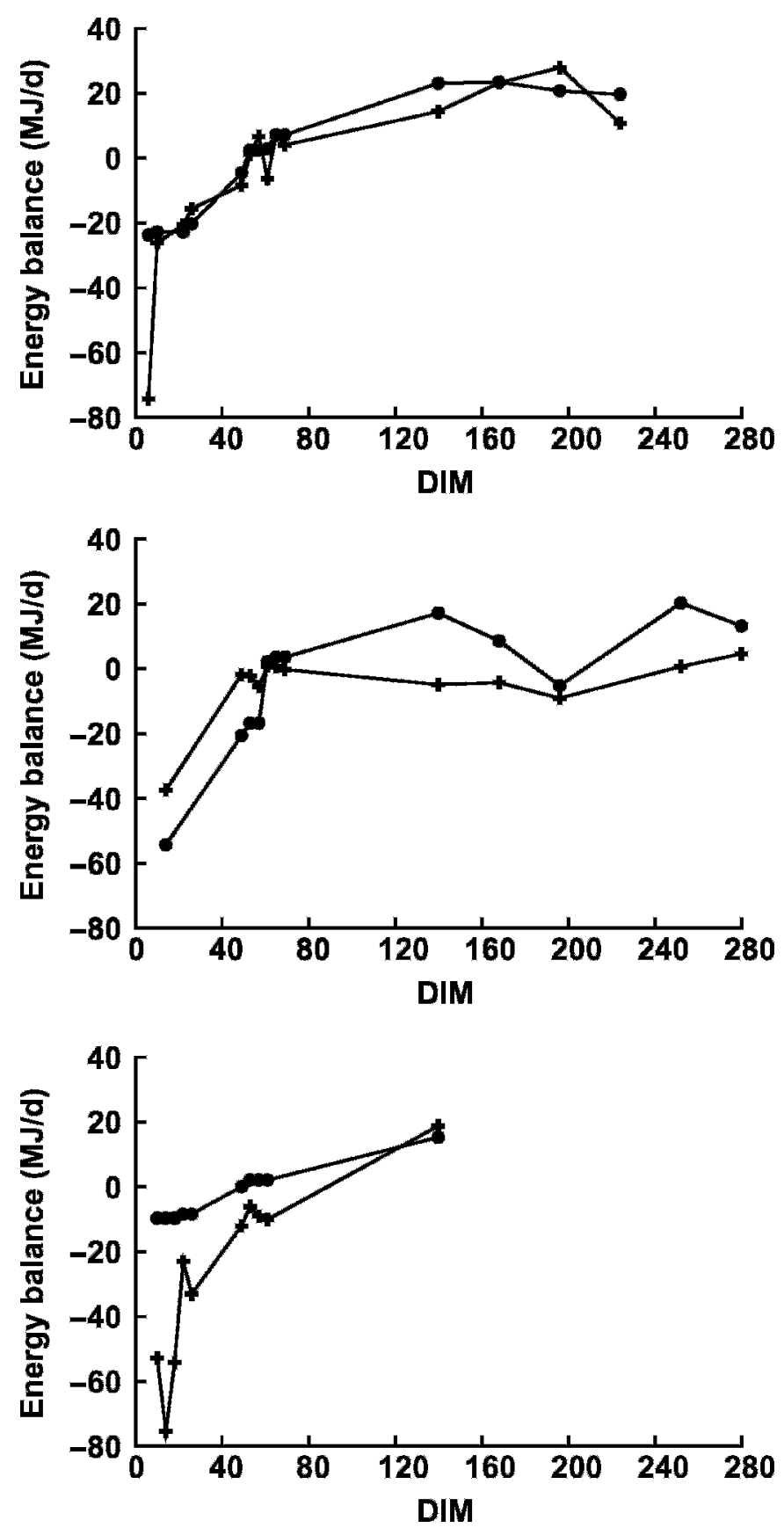

Figure 6. Three example plots of individual predicted (+) and actual (@) energy balance profiles relative to DIM. Actual energy balance was calculated from changes in BW and BCS.

respectively. This could indicate that energy balance calculated from BW and BCS was more error prone than the traditional EBinout. But, the $\mathrm{R}^{2}$ of a regression of EBinout on EBal was $91 \%$. Further, visual inspection of individual lactation curves of the 2 calculated energy balances with the milk composition-predicted values did not show that EBal was more variable through time

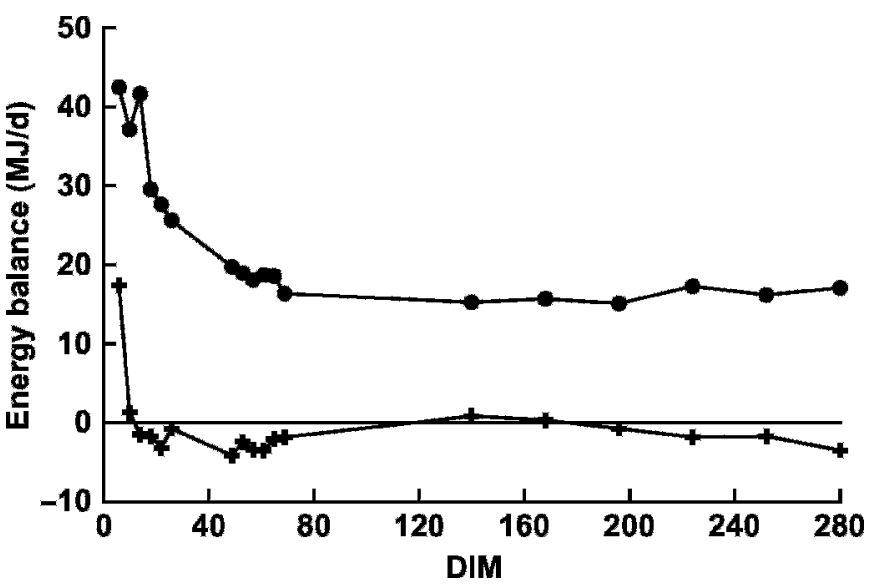

Figure 7. The average (+) and standard deviation $(\bullet)$ of the residuals from prediction of individual energy balance using partial least squares regression model 18 relative to DIM. Energy balance was calculated from changes in BW and BCS.

than EBinout but instead showed that there were similar time-related fluctuations in both EBinout and the milk composition predicted values. Thus, the increase in $\mathrm{R}^{2}$ was due to the in-built correlation arising from milk composition measures being in both the predicted and the EBinout values and was not indicative of a lower accuracy of the BW- and BCS-derived EBal calculation.

The finding that group mean-derived predictions have limited accuracy for predicting individual EBal (Figure 6) does not mean that the energy balance of individual cows cannot be predicted from milk composition measures. Rather, this should be taken as an indication that more sophisticated models for individual cow prediction should be explored. In the present study, no attempt was made to adjust the data for systematic between-animal differences (permanent environmental effects). This could be done using REML methodology and would be a valuable exploratory step for identifying potential causes of individual variation. Similarly, the residuals from applying the group mean PLS prediction to individuals could be further explored. Nevertheless, this type of approach becomes considerably more complicated when the ultimate aim is to develop prediction equations that can be used in real time (i.e., ongoing during lactation) rather than using completed lactation information. As such, this is beyond the scope of the current work but is clearly worthy of future consideration.

Another issue requiring further consideration relates to nutritional management. Although this study clearly shows that there is a strong relationship between energy balance and milk composition, these results are based on data from 1 experiment. This experiment was 
carried out under stable feeding conditions, and so this study was not able to estimate the robustness of energy balance predictions across different feeding situations. It is known that milk composition, including milk composition ratios, is affected by feed composition (Beever et al., 2001); we do not currently know the extent to which this affects prediction of energy balance.

\section{CONCLUSIONS}

The average energy balance of different parities of Holstein, Danish Red, and Jersey cows can be predicted throughout lactation using 1 common equation based on DIM, milk yield, milk fat, and milk protein measures. When derived from daily milk measures, the average error of prediction was very low.

\section{ACKNOWLEDGMENTS}

We gratefully acknowledge the valuable contribution of Gitte Munch, who did all the condition scoring and Hanne Marie Nielsen, Peter Trier, Connie Middelhede, and the farm staff at Ammitsbøl Skovgård, Danish Cattle Association, Skejby. This study, which was part of the Biosens project used data from the "Mælkekoens energibalance og mobilisering" project; both were funded by the Danish Ministry of Food, Agriculture and Fisheries and the Danish Cattle Association.

\section{REFERENCES}

Bareille, N., F. Beaudeau, S. Billon, A. Robert, and P. Faverdin. 2003. Effects of health disorders on feed intake and milk production in dairy cows. Livest. Prod. Sci. 83:53-62.

Beever, D. E., J. D. Sutton, and C. K. Reynolds. 2001. Increasing the protein content of cow's milk. Aust. J. Dairy Technol. 56:138-149.

Cammell, S. B., D. E. Beever, J. D. Sutton, J. France, G. Alderman, and D. J. Humphries. 2000. An examination of energy utilisation in lactating dairy cows receiving a total mixed ration based on maize silage. Anim. Sci. 71:585-596.

Chilliard, Y., B. Rémond, J. Agabriel, J. Robelin, and R. Verite. 1987. Variations du contenu digestif et des reserves corporelles au cours du cycle gestation-lactation. Bull. Tech. CRZV Theix INRA 70:117-131.

Coffey, M. P., G. C. Emmans, and S. Brotherstone. 2001. Genetic evaluation of dairy bulls for energy balance traits using random regression. Anim. Sci. 73:29-40.

Dillon, P., F. Buckley, P. O'Connor, D. Hegarty, and M. Rath. 2003. A comparison of different dairy cow breeds on a seasonal grassbased system of milk production. 1. Milk production, live weight, body condition score and DM intake. Livest. Prod. Sci. 83:21-34.

Ellis, J. L., F. Qiao, and J. P. Cant. 2006. Evaluation of net energy expenditures of dairy cows according to body weight changes over a full lactation. J. Dairy Sci. 89:1546-1557.

Emmans, G. C. 1994. Effective energy: A concept of energy utilization applied across species. Br. J. Nutr. 71:801-821.

Fourichon, C., H. Seegers, N. Bareille, and F. Beaudeau. 1999. Effects of disease on milk production in the dairy cow: A review. Prev. Vet. Med. 41:1-35.

Friggens, N. C., P. Berg, P. Theilgaard, I. R. Korsgaard, K. L. Ingvartsen, P. L. Løvendahl, and J. Jensen. 2007. Breed and parity effects on energy balance profiles through lactation: Evidence for genetically driven body reserve change. J. Dairy Sci. 90:52915305.

Friggens, N. C., and M. G. G. Chagunda. 2005. Prediction of the reproductive status of cattle on the basis of milk progesterone measures: Model description. Theriogenology 64:155-190.

Friggens, N. C., G. C. Emmans, and R. F. Veerkamp. 1999. On the use of simple ratios between lactation curve coefficients to describe parity effects on milk production. Livest. Prod. Sci. 62:1-13.

Friggens, N. C., and K. L. Ingvartsen. 2002. The importance of mobilisation and deposition of body reserves for calculation of energy requirements. Pages 56-61 in Boologisk Selskabs Seminar. Dansk Boologisk Selskab, Brædstrup, Denmark.

Friggens, N. C., K. L. Ingvartsen, and G. C. Emmans. 2004. Prediction of body lipid change in pregnancy and lactation. J. Dairy Sci. 87:988-1000.

Grieve, D. G., S. Korver, Y. S. Rijpkema, and G. Hof. 1986. Relationship between milk composition and some nutritional parameters in early lactation. Livest. Prod. Sci. 14:239-254.

Hanigan, M. D., L. A. Crompton, B. J. Bequette, J. A. N. Mills, and J. France. 2002. Modelling mammary metabolism in the dairy cow to predict milk constituent yield, with emphasis on amino acid metabolism and milk protein production: Model evaluation. J. Theor. Biol. 217:311-330.

Heuer, C., W. M. Van Straalen, Y. H. Schukken, A. Dirkzwager, and J. P. T. M. Noordhuizen. 2000. Prediction of energy balance in a high yielding dairy herd in early lactation: Model development and precision. Livest. Prod. Sci. 65:91-105.

Heuer, C., W. M. Van Straalen, Y. H. Schukken, A. Dirkzwager, and J. P. T. M. Noordhuizen. 2001. Prediction of energy balance in high yielding dairy cows with test-day information. J. Dairy Sci. $84: 471-481$.

Höskuldsson, A. 1994. The H-principle: New ideas, algorithms, and methods in applied mathematics and statistics. Chemom. Intell. Lab. Syst. 23:1-28.

Kristensen, T. 1986. Method for estimation of body condition of dairy cows. Natl. Inst. Anim. Sci., Tjele, Denmark.

Lowman, B. G., N. Scott, and S. Somerville. 1976. Condition scoring of cattle. Tech. Bull. 6:1-29. East of Scotland Coll. Agric., Edinburgh, Scotland.

Luiting, P. 1999. The role of genetic variation in feed intake and its physiological aspects: Results from selection experiments. Pages 75-87 in Regulation of feed intake. Proc. 5th Zodiac Symp., Wageningen, the Netherlands. CAB Int., Wallingford, UK.

Nielsen, H. M., N. C. Friggens, P. L. Løvendahl, J. Jensen, and K. L. Ingvartsen. 2003. The influence of breed, parity and stage of lactation on lactational performance and the relationship between body fatness and live weight. Livest. Prod. Sci. 79:119-133.

NRC. 2001. Nutrient Requirements of Dairy Cattle. 7th ed. Natl. Acad. Press, Washington, DC.

Veerkamp, R. F., G. C. Emmans, A. R. Cromie, and G. Simm. 1995. Variance components for residual feed intake in dairy cows. Livest. Prod. Sci. 41:111-120.

Wood, P. D. P. 1980. Breed variations in the shape of the lactation curve of cattle and their implications for efficiency. Anim. Prod. 31:131-141.

Wright, I. A., and A. J. F. Russel. 1984. Estimation in vivo of the chemical composition of the bodies of mature cows. Anim. Prod. $38: 33-44$.

\section{APPENDIX}

\section{Derivation of Energy Balance from Measures of Body Reserve Change}

Energy balance derived from changes in body reserves (EBal) is defined as:

$$
\mathrm{EBal}=\mathrm{z} \times \Delta \mathrm{L}+\mathrm{y} \times \Delta \mathrm{P},
$$


where $\Delta \mathrm{L}=$ the rate of change of body lipid $(\mathrm{kg} / \mathrm{d}) ; \Delta \mathrm{P}=$ the rate of change of body protein $(\mathrm{kg} / \mathrm{d}) ; \mathrm{z}=$ the energy associated with a kilogram of lipid $(\mathrm{MJ} / \mathrm{kg}) ; \mathrm{y}=$ the energy associated with a kilogram of protein $(\mathrm{MJ} / \mathrm{kg})$.

When body reserves are being mobilized (i.e., $\Delta \mathrm{L}$ or $\Delta \mathrm{P}$, or both, are negative), $\mathrm{z}$ and $\mathrm{y}$ represent the amount of energy made available. This is the energy content of lipid and protein minus the energy cost of the work of mobilizing said reserves. When body reserves are being deposited ( $\Delta \mathrm{L}$ or $\Delta \mathrm{P}$, or both, are positive), $\mathrm{z}$ and $\mathrm{y}$ represent the amount of energy required. This is the energy content of lipid and protein plus the energy cost of the work of depositing said reserves. The values of $\mathrm{z}$ and $\mathrm{y}$ are well defined and are robust to differences among breeds (Emmans, 1994; Friggens and Ingvartsen, 2002).

Using the following base equations, $\Delta \mathrm{P}$ can be derived from consideration of empty $\mathrm{BW}$ (EBW; kg), lipid mass $(\mathrm{L} ; \mathrm{kg})$, and the protein content of the lipid-free empty body (LFEB; kg):

$$
\begin{aligned}
\mathrm{LFEB} & =\mathrm{EBW}-\mathrm{L} \\
\mathrm{P} & =\mathrm{k} \times \mathrm{LFEB},
\end{aligned}
$$

where $\mathrm{k}=$ the protein content of LFEB and $\mathrm{P}=$ the protein mass $(\mathrm{kg})$. This has been shown to change with degree of maturity, but within the range of degrees of maturity, typically 0.85 to 1 , of lactating dairy cows, $\mathrm{k}$ can be assumed to be constant.

$$
\begin{aligned}
\mathrm{y} \times \Delta \mathrm{P} & =\mathrm{y} \times\left(\mathrm{P}_{2}-\mathrm{P}_{1}\right) \\
& =\mathrm{y} \times\left(\mathrm{k} \times \mathrm{LFEB}_{2}-\mathrm{k} \times \mathrm{LFEB}_{1}\right) \\
& =\mathrm{y} \times \mathrm{k} \times\left[\left(\mathrm{EBW}_{2}-\mathrm{L}_{2}\right)-\left(\mathrm{EBW}_{1}-\mathrm{L}_{1}\right)\right] \\
& =\mathrm{y} \times \mathrm{k} \times \Delta \mathrm{EBW}-\mathrm{y} \times \mathrm{k} \times \Delta \mathrm{L} .
\end{aligned}
$$

Given that EBW is defined as BW minus gutfill (Gut):

$$
\mathrm{EBW}=\mathrm{BW}-\mathrm{Gut},
$$

and it is assumed that Gut does not vary in a systematic way between time 1 and 2 (and other non-EBW changes, e.g., conceptus growth, are negligible, then the above equation simplifies to:

$$
\mathrm{y} \times \Delta \mathrm{P}=\mathrm{y} \times \mathrm{k} \times \Delta \mathrm{BW}-\mathrm{y} \times \mathrm{k} \times \Delta \mathrm{L} .
$$

Substituting equation [3] in [1]:

$$
\begin{aligned}
\mathrm{EBal} & =\mathrm{z} \times \Delta \mathrm{L}+\mathrm{y} \times \mathrm{k} \times \Delta \mathrm{BW}-\mathrm{y} \times \mathrm{k} \times \Delta \mathrm{L} \\
& =(\mathrm{z}-\mathrm{y} \times \mathrm{k}) \times \Delta \mathrm{L}+\mathrm{y} \times \mathrm{k} \times \Delta \mathrm{BW} .
\end{aligned}
$$

The rate of change of body lipid $\Delta \mathrm{L}$ can be derived from consideration of EBW and empty body lipid proportion (Lprop; g/g):

$$
\mathrm{L}=\mathrm{EBW} \times \text { Lprop }
$$

It has been shown (Wright and Russel, 1984; NRC, 2001) that Lprop is linearly related to condition score (CS), therefore:

$$
\mathrm{L}=\mathrm{EBW} \times(\mathrm{a}+\mathrm{b} \times \mathrm{CS}),
$$

where $\mathrm{a}$ and $\mathrm{b}$ are constants (here assumed to be breed-independent).

Given that:

$$
\begin{aligned}
\Delta \mathrm{L} & =\mathrm{L}_{2}-\mathrm{L}_{1} \\
& =\mathrm{EBW}_{2} \times\left(\mathrm{a}+\mathrm{b} \times \mathrm{CS}_{2}\right)-\mathrm{EBW}_{1} \times\left(\mathrm{a}+\mathrm{b} \times \mathrm{CS}_{1}\right) \\
& =\mathrm{a} \times \Delta \mathrm{EBW}+\mathrm{b} \times\left(\mathrm{CS}_{2} \times \mathrm{EBW}_{2}\right. \\
& \left.-\mathrm{CS}_{1} \times \mathrm{EBW}_{1}\right)
\end{aligned}
$$

substituting [2] in [5]:

$$
\begin{aligned}
\Delta \mathrm{L} & =\mathrm{a} \times \Delta \mathrm{BW}+\mathrm{b} \times\left[\mathrm{CS}_{2} \times\left(\mathrm{BW}_{2}-\mathrm{Gut}_{2}\right)\right. \\
& \left.-\mathrm{CS}_{1} \times\left(\mathrm{BW}_{1}-\mathrm{Gut}_{1}\right)\right] \\
& =\mathrm{a} \times \Delta \mathrm{BW}+\mathrm{b} \times\left(\mathrm{CS}_{2} \times \mathrm{BW}_{2}-\mathrm{CS}_{2} \times \mathrm{Gut}-\mathrm{CS}_{1}\right. \\
& \left.\times \mathrm{BW}_{1}+\mathrm{CS}_{1} \times \mathrm{Gut}\right) \\
& =\mathrm{a} \times \Delta \mathrm{BW}+\mathrm{b} \times \Delta(\mathrm{CS} \times \mathrm{BW}) \\
& -\mathrm{b} \times \text { Gut. } \Delta \mathrm{CS} .
\end{aligned}
$$

Finally, substituting [6] in [4]:

$$
\begin{aligned}
\mathrm{EBal} & =(\mathrm{z}-\mathrm{y} \times \mathrm{k}) \times[\mathrm{a} \times \Delta \mathrm{BW}+\mathrm{b} \times \Delta(\mathrm{CS} \times \mathrm{BW}) \\
& -\mathrm{b} \times \text { Gut } \times \Delta \mathrm{CS}]+\mathrm{y} \times \mathrm{k} \times \Delta \mathrm{BW} \\
& =(\mathrm{a} \times \mathrm{z}-\mathrm{a} \times \mathrm{y} \times \mathrm{k}+\mathrm{y} \times \mathrm{k}) \times \Delta \mathrm{BW} \\
& +(\mathrm{b} \times \mathrm{z}-\mathrm{b} \times \mathrm{y} \times \mathrm{k}) \times \Delta(\mathrm{CS} \times \mathrm{BW}) \\
& -(\mathrm{b} \times \mathrm{z} \times \text { Gut }-\mathrm{b} \times \mathrm{y} \times \mathrm{k} \times \text { Gut }) \times \Delta \mathrm{CS} .
\end{aligned}
$$

Therefore, the component variables of energy balance calculated from measures of change in body reserves are $\Delta \mathrm{BW}, \Delta \mathrm{CS}$, and $\Delta(\mathrm{CS} \times \mathrm{BW})$. To calculate this energy balance, estimates of a, b, Gut, $\mathrm{k}, \mathrm{y}$, and $\mathrm{z}$ are required. As described above, $\mathrm{k}, \mathrm{y}$, and $\mathrm{z}$ can be regarded as universal constants that are known. Nevertheless, although estimates of $a, b$, and Gut exist (Chilliard et al., 1987; Friggens et al., 2004), they can be expected to vary according to breed and other factors such as the local diet and CS scale in use. 